\title{
Changing the Content of the Subject of Technology
}

\author{
Marijana Juralovich \\ Faculty of Natural Sciences, Didactics of Household Culture, Vilnius Pedagogical University, Vilnius, Lithuania
}

Email address:

juralovic@bk.ru

\section{To cite this article:}

Marijana Juralovich. Changing the Content of the Subject of Technology. International Journal of Education, Culture and Society. Vol. 6, No. 4, 2021, pp. 144-152. doi: 10.11648/j.ijecs.20210604.17

Received: June 24, 2021; Accepted: August 10, 2021; Published: August 18, 2021

\begin{abstract}
Creation is an important reflection of the internal and external world of the pupil, an expression of his or her own individuality. When a child creates, he or she expresses his or her feelings, attitudes toward the surrounding world, and what lies within the child: feelings, experiences, thoughts, wishes, needs, objectives and dreams. Thus, the lessons of technology form the perfect environment to stimulate the creative origins of pupils and develop their creativity. The vertical questionnaire survey has been carried out in May - June 2017, in order to clarify the issues of technology subject while developing the technological competencies of different genders (boys and girls) having a direct impact on personal development, to find out the most evaluated programme of technology subject by pupils and the effect of learning according to one or another programme in a mixed or non-mixed group to learning motivation and wish to learn technology. After having analysed the common programmes of basic technological education, it was found out that definition - "suitable for all pupils regardless of gender" showed many didactic and psychological gaps of the programme, as well as serious objections to reality. The programme lacks attention to pupil's growth as healthy personality. Therefore, in order to educate technologically literate, curious, thinking, creative, proactive, responsible and comprehensively healthy personality, it is necessary to consider the natural qualities of pupils, development of boys and girls age phases, psychological and physiologic meaning, flights and abilities, create the opportunities for all pupils (considering the gender) to learn various technologies. The carried-out survey showed that the textile programme is the least valued by pupils $(18,8 \%)$; the programme of constructional materials is also less valued $(29,6 \%)$. A relatively large number of pupils $(40,3 \%)$ think that learning motivation is stronger and the results are better during the learning of technology in a non-mixed group. Equal distribution of all programmes without dividing boys and girls by their gender, as specified in common programmes, is not logical. Girls need more time to learn in the textile division, in order to be more feminine. To become more masculine, boys should devote more time to the division of construction materials. The assessment of various technological programmes (nutrition, construction materials, textiles), in the pupils ${ }^{6}$ opinion, showed that the natural qualities of boys (as men) and girls (as women) are educated only partially. Therefore, the pupil is not educated as a personality.
\end{abstract}

Keywords: Creativity, Technology Subject Programs, Gender Development of Personality, Learning Motivation

\section{Introduction}

Our society is governed by professional politicians. People strive for more production and consume more. All activities are aimed at economic goals, measures become goals, people are "vending machines" - well-fed, well-dressed, but they do have their own special human purpose. For a man to be able to love, he must feel exceptional. According to G. Gedvilienè and others [14], R. Čiužas [6], a learning teacher must become the norm, a way of life. Professional educators seek to abandon the twentieth century school model, in which the most talented were taught and others were left out, and to move to innovative education to create equal opportunities and prepare them for the knowledge society in which they will live and work [26, 27]. Love is the only answer to the question of human existence, so it does not allow the natural needs of man to be destroyed. True love includes caring, respect, responsibility, cognition. "It is through an active effort born of the ability to love that the loved one will grow and be happy" [10]. Oaklander [33] agrees: "Creativity is an important reflection of the student's inner and outer world, an expression of individuality. When creating, the child consciously or unconsciously expresses his own feelings and attitudes towards the world around him“. When creating, a child 
expresses everything that lies within him: his feelings, experiences, thoughts, desires, needs, goals, dreams and fantasies. $<\ldots>$ We do not necessarily have to be similar to each other - similar must be our approach to the most important issues in life, writes R. Želvis [50]. Technology lessons are available as a great medium to stimulate students' creative beginnings, to develop their creativity, positive thinking, and instill moral values. Quality, according to P. Geoff [36], is created by a strategy, so let us build a happy future "through the eyes of students."

Investigation problem. As technological education in Lithuania is analyzed in a fragmentary way, there is a problem with studying the subject of technology "through the eyes of students".

The aim of the research is to analyze the changes in the content of the technology subject and the students' subject evaluation interfaces.

\section{Research Tasks}

1) To perform the analysis of the general programs of the basic education of the subject of technology;

2) Assess the importance of personality development during technology lessons, taking into account gender;

3) To determine the opinion of students about technology subject programs, studying in a mixed and non-mixed group;

4) To summarize the main problems related to personality development during technology lessons, taking into account gender.

\section{Research Methods}

1. Theoretical: analysis of theoretical and subject methodological literature on the issues under consideration, analysis and generalization of international and national educational documents, theoretical modeling methods used to analyze students' attitudes and their influence on personality, the importance of professional competencies in a period of changing educational paradigms. 2. Empirical research methods: quantitative (student questionnaires) and qualitative (interviews with students, observation, preparation of shortterm and long-term projects) and execution, Learning Research. Those methods allow the author to constantly "from within" observe how students evaluate the subject of problems of this kind to be considered together with educators in the process of student education. A questionnaire survey of students in grades 6-9 was conducted. The computer program SSPS (Statistical Package for the Social Sciences) 22 for Windows was used to perform mathematical statistical analysis of research data analysis, and an Excel program was used to graphically represent the study's results.

Analysis of general curricula of technology subject basic education. The expertise of technology teachers, as well as the subject's nuances, enable them to foster students' creativity and self-development. The topic of technology was dubbed "household culture" in 1993 [44]. 1993, 1994, 1997 [28, 29], employment and The aim of household culture was to create conditions for each student to acquire knowledge and form skills and values to understand the value of mental and physical work to the individual, the family, society, as well as the ethical, social and environmental aspects and their significance, functionally, economically, aesthetically planned, organized and the household, understand the principles of healthy eating, lifestyle and nursing, get acquainted with the principles, methods, technologies of creation of objects and the material environment in the world of things as a consumer, to choose a profession wisely, to develop a creative, thinking personality capable of solving the various problems of life. After evaluating the connections between the type of technological education of craft production (prevailing until 1997) with changes in public life, the aim is to expand this type, i.e., to complement the creative aspect. Project technological education is a type of extended craft production education in which students' practical as well as project technological abilities grow. This type of technological education promotes student independence and aids in problem solving. The project technological education form is used in the implementation of the technological education program and is appropriate for all students, regardless of gender. Since 2001, "work and technology subjects" in general have been referred to in schools as "technology." At present, the following are observed in Lithuania in the direction of curriculum renewal: to orient the curriculum toward the development of general competencies, particularly creativity and essential subject competencies [35], the basic curricula for basic education were updated in 2008 in accordance with the provisions of the State Education Strategy 2003-2012 [7]. General education curriculum [8], technological education, is perceived as creative and the production process as a whole. Technological education is an integral part of holistic education that enables students to become technologically literate, capable of continuous acquisition of new knowledge and developing technological skills to understand, use and evaluate ongoing technological development in the creative (practical) process by forming a positive attitude towards technology's transformation in the context of the past, the present and the future. Also, the process of technological education takes place without dividing students by gender. The phrase "applies to all students regardless of gender" reveals many didactic and psychological gaps in the program and bumps into reality. This provision clearly conflicts with the purpose of the subject, technological educational purposes, objectives and didactic attitudes. The program lacks attention to the growth of the student as a personality. Didactic attitudes: technological education perceived as a continuous seamless process that seeks to link theory and practice contextual interfaces: past - present - technology healthy, safe and aesthetic lifestyle - consumer entrepreneurship - world of work. Purpose of the subject: The aim is to develop a technologically literate, curious, thoughtful, creative, proactive and responsible personality. 
The goal of technological education is to lay the groundwork for students to learn the fundamentals of technological literacy, as well as to instill values and general technological abilities that will allow them to experience creative joy. Technological education must also awaken students' "creative beginnings." So in order to develop a technologically literate, curious, thinking, creative, proactive, responsible and fully healthy personality, it is simply necessary to take students into account natural traits, psychological and physiological age stages of boys and girls development, their needs and abilities, to enable all students (according to gender) learn different technologies. 2012 in the general curriculum of primary education. education is perceived as an integral part of holistic education that allows students to become technologically literate, able to constantly acquire new knowledge and develop technological skills, to understand, use and evaluate continuous technological development in the creative (practical) process by forming a positive attitude towards the transformation of technologies in the context of the past, present and future. Technological education is perceived as continuous (from preschool and preschool children to technological gymnasium), an integrated process to link theory and practice with contextual interfaces: past present - technology - healthy, safe and aesthetic lifestyle consumers - entrepreneurship - the world of work. One of the tasks of technological education is to stay healthy. E. Žilinskienè, V. Gudžinskienè [53], J. Sondaite [38], J. Bokemiūlis [3], state that intellectual interests change during adolescence. Curriculum development and education methods still do not take sufficient account of the cognitive development of adolescents, so some pupils lose interest in science during adolescence. Adolescent non-learning is constantly accompanied by conflicts at school. When discussing the links between non-learning and conflict, it is important to note that pedagogical theory does not agree. The goals of education also have a negative effect on volatility. "A problem is the constant change of teaching goals, as well as didactics and methods $<\ldots>$ ". The approach to school as an experimental landfill, the introduction of new teaching methods, the overloading of curricula with scientific information are the reasons why "the psyche of teenagers suffers". In the general programs of the Lithuanian general education school (1994, 1997, 2002 and 2003, 2008, 2011) [28-31, 34, 35], when discussing the content of education, they also focus on general students' development of competencies, emphasis on human values - mutual understanding, respect for oneself and others, respect for democracy, respect for national traditions, patriotism, tolerance, thrift, caring for others, honesty, responsibility, initiative and the importance of creativity, the pursuit of quality, and a healthy lifestyle - education. Basic general education curricula are stated by using active teaching and learning methods $\langle\ldots>$ while taking into account students' needs and abilities, in order to create conditions for all students (regardless of gender) to learn about various technologies. According to K. Grinkevičius, R. Noreika [18], when implementing the latest programs, there must be an essential change in teaching methods. Therefore, it is especially important to take gender into account when selecting certain methods. According to E. Jovaiša [23], gender differences are not only anatomical, physiological, but also personality. The main aspects of technological education have an impact on the planning and organization of the educational process.

\subsection{The Importance of Personality Development During Technology Lessons, Taking into Account Gender}

The concept of culture in the household is broad and complex. We can not talk about any culture without introducing cleanliness, order, behavioral and cultural habits, without developing a sense of beauty. The basics of household culture are obtained in the family at an early age. It was later converted into a kindergarten school. An integral part of household culture is the pursuit of beauty and the development of taste. Clutter indicates a poor household culture. The constant search for items is already a sign of clutter. Interpersonal relationships are perhaps the most visible manifestation of a household culture. External behavior usually reflects internal culture, human attitudes, and even thinking. Only uncultured, unpleasant words are heard in the family. In a cultural family, all conflicts are resolved quietly, calmly. The problems of the wife-husband relationship in the family need to be addressed culturally: not who will rule, but help each other as much as possible. A harmonious family relationship between parents, between parents and children, relations in society already show the level of people's culture [24]. S. Cowley [4] agrees, arguing that having a positive attitude can help us build a good relationship. Sustainability is contagious, as is disharmony. The idea of passing emotions on to others has been quite popular in recent years and has been thoroughly investigated [2]. The family is the social system, and the household is the economic system [13]. The program on family culture (1993, 1994) perfectly reflects the aspects of family preparation. The importance of personality development in terms of gender was emphasized in 2016. The Minister of Education and Science Audron Pitrnien approved Health and Sexuality on October 25th in the general program for family education and training, which went into effect on September 1st, 2017 [40]. The purpose of the program is to ensure the successful education of a child's health and sexuality and preparation for the family at school, to contribute to the child's spiritual, physical, mental, social well-being and successful functioning in the areas of work, interpersonal relationships and family. Health safety in educational institutions is manifested in the creation of a safe environment for students, the organization of the educational process in compliance with hygiene norms and in compliance with education law.

The program is based on the legalization of the Law on the Health System of the Republic of Lithuania and the concept of health: health is the physical, spiritual and social wellbeing of an individual and society. Physical health is understood as a condition of the human body, when it functions integrally, does everything itself, does not get sick, 
does not have a disability. Mental health is understood as a state of inner well-being manifested by an adequate perception of reality, the expression of personality powers, and emotional and spiritual resilience to the ordinary challenges of life. Social health is understood as a state that includes positive selfesteem and self-esteem, satisfaction with interpersonal relationships, and the ability to communicate. Sexuality - a person's gender identity, revealed through himself as a man or woman, a person of the opposite sex, the world around him manifests itself in biological, mental, socio-cultural, and spiritual aspects of human existence.

The program is implemented in accordance with the principles of integrity, accessibility, personalization, respect for human beings and gender equality, synergy, and discretion (restraint) principles. Technological education creates preconditions for students to develop technological self-expression, creativity and the flexibility to choose what is necessary for everyone, regardless of gender, in an everchanging socio-cultural environment, to be able to use simple technologies as consumers, to experience solutions to creative problems, to develop positive attitudes towards constant technological change [35] and creativity. The concept of technological education was introduced in Lithuania in the 20th century, and changes have emerged in this area only since 2000 [39]. J. K. Galkauskas [12] examines the historical development of the concept of technology. The development of the concept of technology in general in the education system examines V. Augustinavičius [1]'s students' attitudes towards technology. The analysis of the concept is presented by A. Ramanauskaite, N. Stankevičienè, L. Šiaučiukienè [37]. According to A. Ramanauskaitė [37], K. Grinkevičius, R. Noreika [18] examined the essential changes in technological teaching methods. Z. Žebrauskienè [49], B. Žygaitienè, J. Česnavičienė, D. Švelnienè, E. Vaivadienè, A. Numgaudienè, K. Pošiūnaitė [51, 52] examine issues of technological education, I. Valantinaite, R. Zablacke [46-48] - creativity problems in developing technological skills. It is noted that when organizing education $(\mathrm{Si})$, it is critical to consider the characteristics of the growing organism, as well as the health requirements of the child.

The education of a person during technology lessons, based on the general programs of basic education of the subject of technology in 2012 [35], is carried out in violation of: 1) the principle of accessibility, as skills and values are only partially developed, which must correspond to the age of the person (boy as a man, and girl as a woman) and peculiarities of the stage; 2 ) the principle of personalization, as the individual of each child is not taken into account, interests; 3 ) the principle of respect for the human person and gender equality, as the natural qualities of a boy (as a man) and a girl (as a woman) are only partially developed.

According to L. Jovaiša [23], gender differences are not only anatomical, physiological, but also differences in personality, behavior, experience resulting from the social environment, education and manifesting themselves with different emotions, cognitive, professional interests, attitudes.
The differences between boys and girls are most pronounced at school. Educators notice and research confirms that girls are more diligent, more obedient to the demands of educators, more emotionally sensitive, and more important in learning activities and humanitarian affairs. They are more subject to the influence of teachers than boys, and their artistic, social and verbal abilities are more pronounced. Boys are not diligent enough and disciplined, characterized by greater aggression and autonomy [11].

It should also be emphasized that girls are more educated in little finger and finger motor skills, dexterity of hands, they are more orderly, and boys are more educated in big motor skills where more muscle work is required $[55,56]$. R. Žukauskienè [54] agrees with this, stating that girls perform simple, faster psychomotor reaction tasks, such as pressing a button quickly when turning on a light bulb. Boys perform better at tasks that require visual control.

Fine motor skills are movements in which the small muscles of the body are involved. These are finger, wrist, coordinated eye and hand movements. Some fine motor skills are related to others and develop in a certain order. Usually, children's movements develop with equal consistency, but the pace of development and the quality of movements may vary. It depends on genetics, gender, environment, motivation, education and other factors [54]. According to some scholars $[55,56]$ boys are more interested in tasks that are valued materially, while girls are more interested in emotional evaluation and praise. Education in fine and large motor skills is a prerequisite for successful school learning.

The desire for security is a natural desire shared by all people, regardless of gender. A woman's need for stability and security is more pronounced than a man's. It provides an opportunity for a man to realize his vocation - to guard, protect, take care of others. The physical weakness of the female sex creates the preconditions for the spread of male masculinity. Female patronage, an exclusively feminine trait, is also the basis of male patronage.

According to Chittapad [5], the arts are a medium for women. This phrase quite accurately describes the power of the arts for women, i.e. for the education of girls, girls, and women. Girls are looking for educators, teachers, from which, with an open heart as a source, they can draw everything without critically analyzing, carefully considering every element of the law, every idea. Boys' perceptions are more critical - they tend to check the truths that are presented to them. Men's intuition, which allows them to unmistakably determine which source is real, is weaker. Men are unable to accept everything so recklessly, but they have a sober mind, the ability to compare, analyze, and their task is to form a personal, individual worldview. And women tend to take over someone's worldview - a father, a beloved man, or even another person. For girls, the environment in which they are brought up, in which they breathe, is far more important than for boys. Girls are more receptive and more influential than boys. Their upbringing and training must be like a celebration. Thoughtful protection of girls from some painful and dirty life events is simply necessary (limitation of some 
things). And restrictions are less necessary for raising boys. They need to be trained to fight opponents in all sorts of ways: fists, brains, ideas, feelings. Boys are educated through struggle, tension, through the onslaught of results, through trials, although the holidays should not be forgotten either. The tasks of educating boys and girls and nurturing their worldview are so diverse that it would be entirely useful for individual educational institutions to be able to collaborate with each other.

According to J. Eldredge [9], society in general is not able to decide what kind of man it needs. She has spent the last thirty years attempting to make masculinity more sensitive, safer, easier to manage, and, admittedly, more feminine $<\ldots>$. Every woman wants to reveal her attractiveness. Not to show, but to reveal. Many girls like to dress up as children, play at weddings, and wear puffy skirts to grab their dad's attention. Boys mimic the behavior of fathers: they like to craft, build, dismantle, create constructions. J. Gray [15] and V. Megel, A. Goncharov [57] state that each child, according to his gender, body type, temperament, personality, intelligence and learning style, has a unique set of characteristics in the universe. Gender differences become apparent in adolescence, but from day one, boys are boys and girls are girls. Recognizing common gender differences makes it easier to accept and respect certain behaviors and needs that seem foreign. Boys usually have special needs that are not very significant for girls. Girls also have needs that are not very important to boys. Of course, everyone needs love. But love can be expressed in many different ways, such as caring and trusting. Caring is a desire to help children and an interest in their well-being and who they are, a desire to make children happy, and compassion when they fail. Trust is the recognition that all is well, the knowledge and belief in one's children's ability to achieve a goal and learn from mistakes; it is observing the spread of a child's traits in the belief that all will be well. Of course, care and trust are needed for every child, but not in the same way. Boys of any age need more trust, while girls need more care. According to some scientists [58, 15], it is much easier to raise children by remembering that boys (like men) are from Mars and girls (like women) are from Venus. If a boy feels powerless to earn trust, recognition, and is underestimated by others, then suppressing the good and bad qualities of his masculinity can make him more like a girl and begin to feel the need for care, understanding, and respect. When it becomes too painful for a boy to feel the need for confidence and not get it, he suppresses his masculine personality traits, thus revealing his feminine qualities and the needs that arise from them at the same time. When too much worry starts to press, the boy becomes whimsical. Sometimes boys are more sensitive, so they don't look masculine. Sensitive boys have more female hormones and fewer male hormones, so their predispositions are more feminine. The striking difference between boys and girls is that boys forget and girls remember. Men and boys, covered by stress, focus more than women and girls on the problem or main task to be solved. The more stress, the more they forget everything except the task. Stress-laden boys are more focused and girls are starting to talk more. Women often do not understand this difference and mistakenly treat men's oblivion as careless. The man frees himself from worry by forgetting what pressures him, and the woman by remembering everything. We care about raising children that we can enjoy and be proud of, according to A. Kurienè [59]. We rush to teach them about all sorts of things, and we explain what is good and what is bad, forgetting that we are raising a person, not a set of knowledge and rules. At each stage of development, certain psychological needs of the child must be met in order for him or her to be able to successfully overcome the challenges posed by that stage. If we want to raise a person, and not create a perfectly functioning apparatus, let us imagine the stages of development as certain construction blocks stacked on top of each other. If in the first year of life, the child learns that the world is a safe place, and the people around it are reliable and ready to provide what it needs, it will be able to start exploring the world on its own in the second year and try to understand how this works, "what people work all day". A student who is enterprising, active, safe, and curious will successfully overcome the school challenge of studying, being friendly, diligent, and responsible. In adolescence, the search for personal identity, its formation and development are important. Empirical studies suggest that this process should be more accurately referred to as non-identity formation, but evolution, but it is agreed that it is a normative process in which both the content and the structure of selfthinking change. Researchers, analyzing identity development in adolescence, describe the changes in adolescent self-image, sense of identity and self-esteem [54].

Every age is qualitatively important. As we move from one age group to another, new formations emerge that did not exist in previous periods. Thus, the course of development itself changes. The age stage is the characteristics of certain living conditions required at a certain stage of a child's development, the characteristics of relationships with others, psychological maturity, the accumulation of knowledge and the maturity of thinking, and a certain set of physiological characteristics.

\subsection{Research Organization and Results}

In order to find out the problems of the subject of technology in educating students of different genders - for boys and girls - technological competencies that have a direct impact on personality formation, as well as to find out what students from technology subject programs value most and how learning according to one or another program in a mixed or In a mixed group, there is a motivation to learn and a desire to learn technology. In May-June a questionnaire survey of students was conducted. The students in grades 6 , 7,8 , and 9 took part in the investigation process. A total of 186 students were interviewed. Compiling the questionnaire, the questions are related to the real situation of the technology subject "through the eyes of the students" while learning in a mixed and unmixed group. The study included 112 girls and 74 boys. 
The study provided key responses that could form the basis for the transformation of the Technology Framework Programs. Health is the personal property of every person. It is determined by a person's ancestors, physical, social, and economic circumstances, but most importantly by his or her own behavior. Therefore, it can be assumed that we treat our children unfairly when creating reckless technology applications.

$60.2 \%$ of students participated in the survey girls and 39.8 percent of boys, so it is possible to assume that there are more girls than boys in schools.

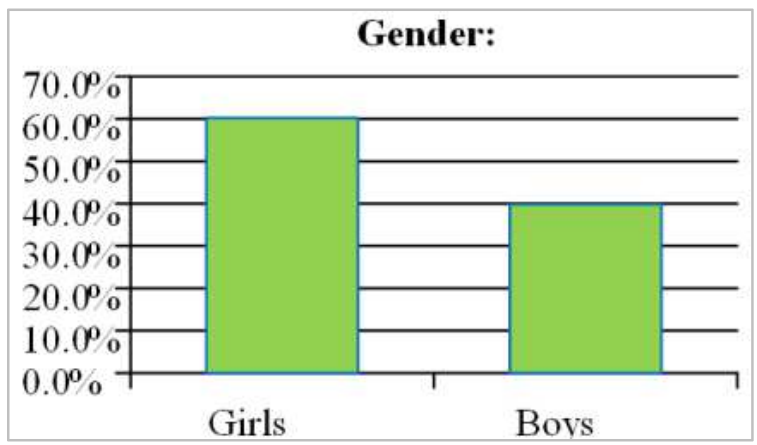

Figure 1. Numbers of girls and boys in the study.

6th, 7th, 8th, 9th grade students participated in the survey.

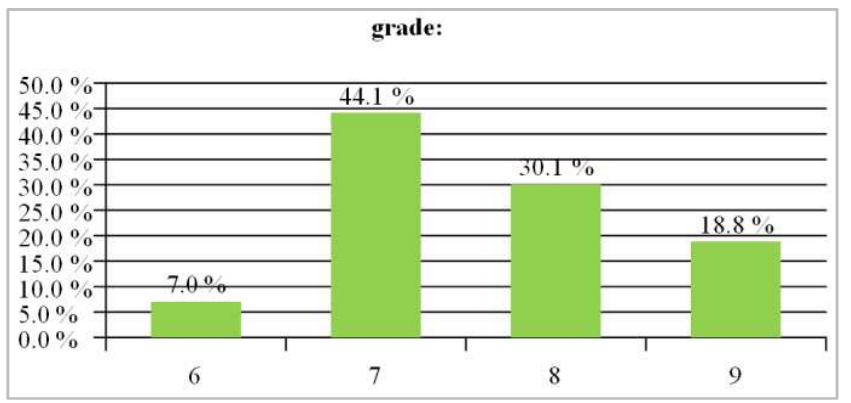

Figure 2. Numbers of 6, 7, 8, 9 grade students who participated in the study.

The question, "Do you study technology in a mixed group all year round?" Answer: $76.9 \%$ study in a mixed group all year round. In the mixed group, 23.1 percent of students did not complete the entire year of study. students.

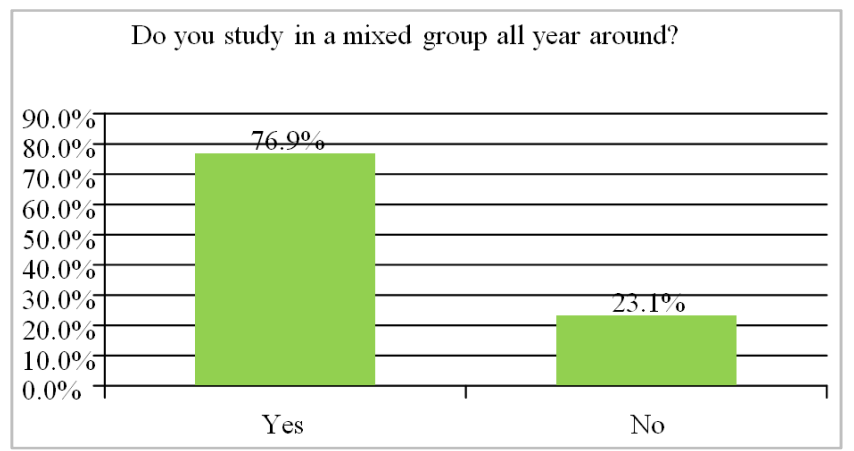

Figure 3. Number of students studying in a mixed group throughout the year.

To the question "Do you like (or would you like) studying in a mixed technology group?" The following answers were obtained: $65.6 \%$ like to study in a mixed group. Students do not like to study in a mixed group. 34.4 percent of students. Most students $(65.6 \%)$ like to study in a mixed group in a "company". A relatively large proportion of students (34.4\%) do not like to study in a mixed group.

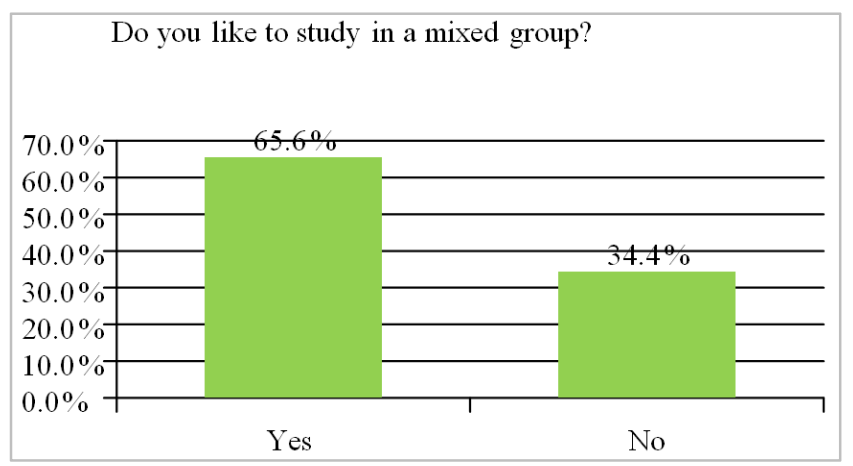

Figure 4. Perceptions of students in the study about learning in mixed groups.

To the question "In your opinion, learning motivation is stronger and results in better learning in a mixed or nonmixed group of technologies? ", I received the following answers: 59.7 percent. Students state that learning motivation is stronger and results in better learning in a mixed group of technologies, at 40.3 percent. Students argue that in a mixed group, learning motivation is higher and results from learning technology are better. A relatively large proportion of students $(40.3 \%)$ believe that learning motivation is stronger and results are better in learning from a mixed group of technologies.

Do you think motivation for learning is stronger and the results are better for students in a mixed-group or non-mixed group?

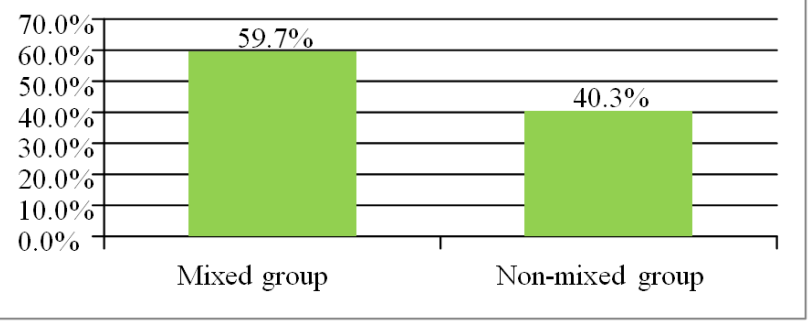

Figure 5. Learning motivation.

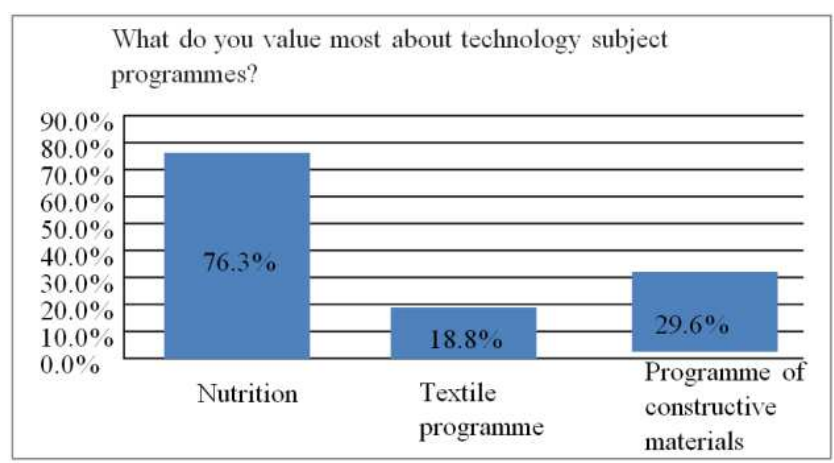

Figure 6. Evaluation of technology subject programs. 
To the question "What do you value most in technology subject programs?" Get the following answers: Nutrition is valued the most by 76.3 percent of students, followed by structural materials at 29.6 percent and textiles at 18.8 percent. It is disappointing that the textile program has become the least valued by students (18.8 percent) and that the construction materials program is also underestimated $(29.6 \%)$.

The survey also revealed the answers to the question "What do boys and girls do in technology subject programs and how do they differ?" Interestingly, the nutrition program is most valued by 51.1 percent of girls and 25.3 percent of boys, the textile program - 15.6 percent of girls and only 3.2 percent of boys, and the construction materials program - 9.1 percent of girls and 22.0 percent of boys.

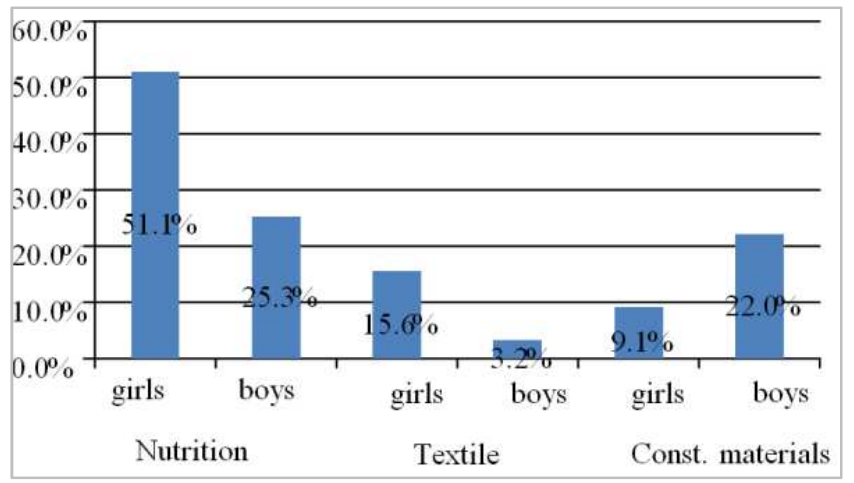

Figure 7. Evaluation of technology subject programs.

From this table, we see marked differences in the needs of girls and boys that are related to their different natural characteristics. Since many authors (Grinienè, Vaitkevičius [16, 17]; Gudžinskienè [19-22]; Šurkienė [41]; Tamašauskas, Stropus [43]; Eldredge [2008]; Chittapad [5]; Sinelnikov [58]; Isaev, Kagan [55, 56]; Gray [15]; Megel, Goncharov [57]; Jovaiša [23]) state that gender differences are not only anatomical, physiological, but also personality, the tasks of upbringing, teaching, choosing learning methods, educating boys and girls and fostering their worldview are very different.

Researchers have shown that the "norm" is when boys have more men and fewer female hormones. As a result, it is natural that their tendencies are more masculine, as the boy must develop a healthy masculine personality. Conversely, the 'norm' is when girls have more female, less male hormones. As a result, it is natural for them to have more feminine tendencies, as a girl must in order to form a healthy female personality.

When a girl doesn't get what she needs, like proper activities for a while during technology lessons, she denies her femininity and becomes "boyish," and when a boy doesn't get what he needs, he becomes "girly" - unmanly.

According to the study, the numbers are very "small," but they are clearly visible to boys: girls prefer the construction materials program more $(22.0 \%)$ than girls $(9.1 \%)$, as they should. In order for a boy to grow up to be "boyish", his body needs to grow more muscular. And girls like the textile program (15.6\%) more than boys $(3.2 \%)$, as it should be. In order for a girl to grow up "girlish", she needs to have more fine motor skills. It can be argued that the textile program is unnecessary for boys or only slightly needed (3.2\%). And the evaluation of the nutrition program among girls (51.1\%) is higher than among boys $(25.3 \%)$. As a result, it can be concluded that equal distribution of all programs without dividing boys and girls by gender, as indicated in the framework programs, is illogical: girls should be allowed to study more in the textile department to grow "girly," and boys should study more in the construction materials department to grow "boyish."

As well as various technology applications (nutrition, construction materials, textiles), assessment through the eyes of 'students' shows that the natural qualities of boys (as men) and girls (as women) are only partially developed.

After grouping the questionnaire students' answers about various technology programs, we received the following results: 56.5 percent would like to study only in the nutrition department. students, only textiles in the department - 5.4 percent. In the department of students, construction materials - 17.2 percent. students. Some students would like to study according to several programs. The conclusion is that students place the least value on the textile program, and the construction materials program is also undervalued.

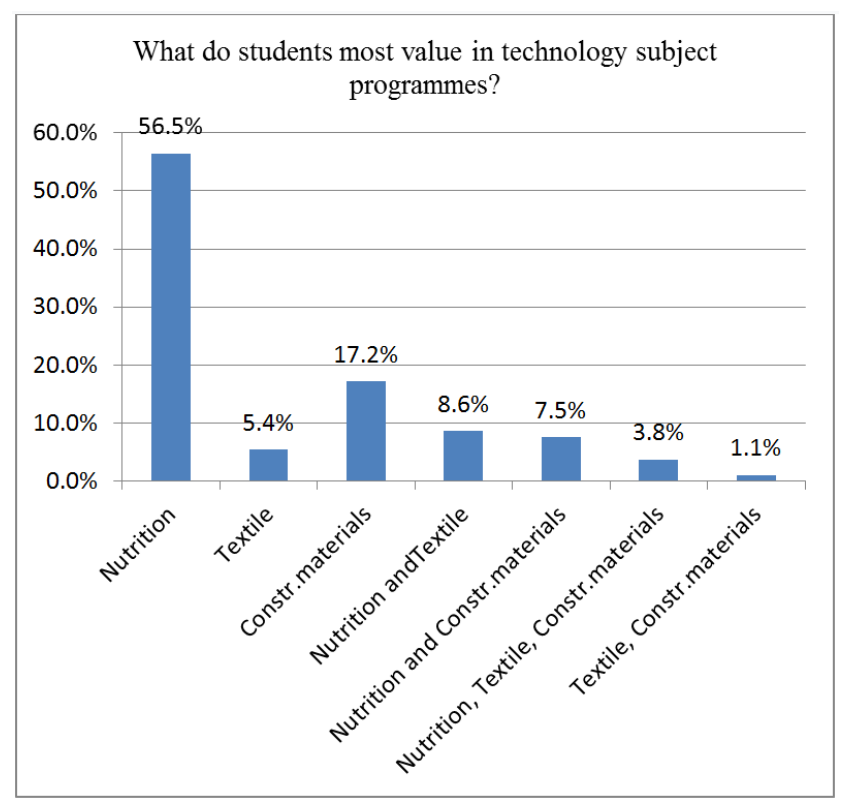

Figure 8. Evaluation of technology subject programs.

\section{Conclusions}

1. Changing paradigms of education - teaching (impact), interaction and learning - directly related to the teacher's work style, teaching objectives, methods, teaching / learning environment, teacher-student interaction.

2. There is a lack of time for the full implementation of the curriculum, not enough methodological materials, information dissemination, cooperation, as well as material base and financing.

3. The competencies of a technology teacher can be linked 
to four European competencies of the qualification structure, the four education for sustainable development competencies and to find out whether they correspond to the description of the competencies of the teaching profession's competencies.

4. In practice, the following problem areas have been identified when applying general programs of basic education to the subject of technology (2008):

1) The textile program has become the least valued by students $(18.8 \%)$, and the materials program is also underestimated (29.6\%);

2) A relatively large proportion of students (40.3\%) believe that learning motivation is stronger and better for learning in a mixed technology group;

3) The student is not educated as a personality because his or her gender is not taken into account. These are major obstacles to planning and organizing a technology subject in the best possible way in the educational process.

\section{Recommendations}

1) In the field of technology didactics, directions of innovative and project activities are not always implemented in practice, as technology lessons are usually organized only for practical technological work;

2) To include the concept of household culture in the general curricula of basic education; and to change the title of the subject to "home culture and technology", which would directly reflect the goal - to educate the student as a fully healthy personality;

3) Take into account the needs of boys and girls in a differentiated (and proportionate) manner; and interests.

\section{References}

[1] Augustinavičius, V. (2002). Explanation of the concept of technology in the general education system. Pedagogy, 62, 103-108.

[2] Boyatzis, R., Mckee, A. (2006). Sustainable leadership. Vilnius: Vilnius Printing House, 286 p.

[3] Bokemiūlis, J. (2000). Sexual maturity and its crises. Vilnius: Lithuanian Waldorf Pedagogical Center publishing house, $23 \mathrm{p}$.

[4] Cowley, S. (2006). Training clinic. Vilnius: Vilnius Press, 153 p.

[5] Chittapad (2005). Spiritual upbringing of children. Kaunas: Mijalba, $153 \mathrm{p}$.

[6] Čiužas, R. (2007). Expression of teachers' didactic competence in the changing educational paradigm (doctoral dissertation: social sciences, educology). Kaunas: Technology.

[7] Regarding the general education plans of the basic and secondary education programs for 2009-2011. Accessvia the Internet: https://eseimas.lrs.lt/portal/legalAct/lt/TAD/TAIS.344620/jeffOYVFUa.
[8] On the approval of general curricula for primary and basic education. Access through internet: https://www.etar.lt/portal/lt/legalAct/TAR.55FA64EA6862.

[9] Eldredge, J. (2008). Wild at heart. Press, 218 p.

[10] Fromm, E. (2013). The art of love. Kaunas: Verba vera, 102 p.

[11] Gage, N. L., Berliner, D. C. (1994). Pedagogical psychology. Vilnius: Alma litera, $624 \mathrm{p}$.

[12] Galkauskas, J. K. (2009). Fundamentals of technology didactics (methodological teaching aid). Vilnius: Vilnius Pedagogical University Publishing House.

[13] Galkauskas, K., Indičanskienè, R., Mielkuvienè, B., Proškuvienè, R., Sederavičiūte, Ž., Sveikauskaitè, A., Urbienis, P., Vitunskienè, V., Žygaitienè, B. (2001). Household cultureand technology (textbook for grade 8). Vilnius: Standartų spaustuvè, $267 \mathrm{p}$.

[14] Gedvilienė, G., Laužackas, R., Lileikienė, T., Mačianskienė, N., Sabaliauskas, T., Sajienè, L., Stasiūnaitienè, E., Teresevičienè, M., Tūtlys, V. (2008). What does a modern teacher need?Relevant content of teacher qualification improvement (textbook for teachers). Vilnius: Lodvila, $174 \mathrm{p}$.

[15] Gray, J. (2016). Children come from heaven. Positive methods of raising children. Vilnius, $335 \mathrm{p}$.

[16] Grinienè, E. (1997). Caring for the health of Šiauliai city students.

[17] Grinienè, E., Vaitkevičius, J. V. (1997). Practical aspects of health education in primary schools. Children's Health Education: Proceedings of an International Conference, Klaipeda, 1997 June 5 Klaipeda, 11-12.

[18] Grinkevičius, K., Noreika, R. (2002). Teachers' professional preparation and preparation for the course "Natureand man": statistics, competencies, needs. Pedagogy, 63, 181-189.

[19] Gudžinskienè, V. (2001). The importance of the basics of critical thinking for the development of a healthy lifestyle. Science education in a general education school: VII Republican Scienceconference proceedings, comp. V. Lamanauskas. Šiauliai, 26-33.

[20] Gudžinskienè, V. (1997). Teaching workload and mental performance of children in primary classes. Pedagogy, 34, 114-121.

[21] Gudžinskienè, V. (2000). The importance of teacher-student communication and collaborationdeveloping critical thinking. Education reform and teacher training: science, studies, school: VII International Scientific Conference. Scientific works. Vilnius, 104-110.

[22] Gudžinskienè, V., Česnavičienè, J. (2002). Health education in the general education system. Pedagogy, 157-162.

[23] Jovaiša, L. (2007). Encyclopedic dictionary of educology. Vilnius: The Mother's Word, $335 \mathrm{p}$.

[24] Kadzijauskienè, I. (1978). Household culture in the family. Internet access: http://laiskailietuviams.en/index.php/1978m10-november/4754-buities-kultura-seima.

[25] Kardelis, K. (2016). Research methodology and methods. Vilnius: Science and EncyclopediasPublishing Center, 487 p. 
[26] Katz, S., Lorna, M., Earl. (2000). School leadership in a datarich world. Kaunas: VitaeLitera, 145 p.

[27] Katz, S., Lorna, M., Earl., Sonia Ben Jaafar (2000). We create and connect learners communities. Kaunas: Vitae Litera, $119 \mathrm{p}$.

[28] General programs of Lithuanian general education school. Projects. (1994). Vilnius: Lithuanian Publishing Center of the Ministry of Education and Science of the Republic, $553 \mathrm{p}$.

[29] General programs of Lithuanian general education school. Classes I to X. (1997). Vilnius: Publishing center, 370 p.

[30] Lithuanian general education school general curricula and education standards. (2002, 2003). Internet access: http://www.upc.smm.lt/ekspertavimas/biblioteka/failai/progra mos.pdf.

[31] General programs of basic education of Lithuanian general education school. (2003). Accessvia the Internet: http://www.smm.lt/uploads/documents/ugdymo-programosarchyvas/Programs2003.pdf.

[32] Description of the competence of the teaching profession. (2007). Vilnius: MES.

[33] Oaklander, V. (2007). Windows to Our Children. Kaunas: Human Psychology Study.

[34] Pacevičiūtè, A., Balsys, M. (2003). General Technology Program and educational standardsbasic school. Vilnius: ŠPC, $28 \mathrm{p}$.

[35] Basic programs of basic education. Technology (primary and basic educationAnnex 9 to the Framework Programs; General programs of basic education for 2008, updated in accordance with the provisions of the State Education Strategy for 20032012).(2012).

[36] Petty, G. (2008). Evidence-based training (practical guide). Vilnius: Tyto alba, $494 \mathrm{p}$.

[37] Ramanauskaitè, A., Stankevičienè, N., Šiaučiukènienè, L. (2001). Concepts of technologythe problem of semantic space. Social Sciences, 4 (30), 33-40.

[38] Sondaite, J. (2001). Peculiarities of adolescents' future orientations (doctoral dissertation manuscript: social sciences, psychology (06 S), Vilnius Pedagogical University). Vilnius, $111 \mathrm{p}$.

[39] Statauskiene, L. (2009). Introduction to technological education (methodological tool). Vilnius: Vilnius Pedagogical University Publishing House, 73 p.

[40] General program of health and sexuality education and family preparation. (2017). ConfirmedMinister of Education and Science of the Republic of Lithuania 2016 October 25 by order no. $\mathrm{V} 941$. Internet access: http://www.smm.lt/uploads/documents/darbo\%20grupes/Progr am\%20preambule_project_finitive.pdf.

[41] Šurkienè, G. (1999). Children's summer recreation hygiene. Vilnius.
[42] Education reform and teacher training: humanism, democracy and citizenshipin school: IV International Scientific Conference: Papers and Abstracts, Vilnius, 1997 October 8-10 Vilnius, $148-152$.

[43] Tamašauskas, R., Stropus, R. (2003). Human anatomy. Kaunas: KMU Publishing House, 317 p.

[44] Technologies. Internet access: http://www.smm.lt/uploads/documents/svietimas/ugdymoprog ramos/9_Technologijos.pdf.

[45] Ustilaitè, S., Purlienè, M., Proškuvienè, R. (2000). Sexuality. Vilnius.

[46] Valantinaite, I. (2012). Attitudes of students in grades V - VI towards creativity, existing knowledge and developed quantitative applicability and evaluation of products. Social Education, 19 (30), 64-76.

[47] Valantinaitè, I. (2012). Technological education as creativity of students in grades 5-6 socio-educational factor (doctoral dissertation manuscript). Vilnius: Edukologija, 202 p.

[48] Valantinaite,, I., Zablacke,, R. (2012). The concept of technological education in updated programs. Pedagogy, 105, $14-19$.

[49] Žebrauskienè, Z., Jurčiukonienè, A. (2002). Improving the educational process of work and household culture lessons. Pedagogy, 62, 109-118.

[50] Želvys, R. (2007). Communication psychology. Vilnius: Margi raštai, $167 \mathrm{p}$.

[51] Žygaitienè, B. (2014). Technological education as moral values, general and professional presumption of acquisition of competencies. Internet access: leu.lt/download/16666/zygaitiene apzvalga pdf.pdf.

[52] Žygaitienė, B., Česnavičienė, J., Švelnienė, D., Vaivadienė, E., Numgaudienè, A., Pošiūnaité, K. (2014). Technological education in Lithuanian general education schools. Vilnius: Lithuanian University of Educational Sciences Publishing House.

[53] Žilinskienè, E., Gudžinskienè, V. (2003). Lifestyle and health. Vilnius: Vilnius Pedagogical University Press, 57 p.

[54] Žukauskienè, R. (2012). Developmental psychology: an integrated approach. Vilnius: Margi raštai, $676 \mathrm{p}$.

[55] Isaev, D. N., Kagan, V. E. (1988). Sex education of children. Leningrad: Medicine, $155 \mathrm{p}$.

[56] Kagan, V. E. (1991). Educator about sexology. Moscow: Pedagogy, $254 \mathrm{p}$.

[57] Megel, V., Goncharov, A. (2002). Characters and relationships. Moscow: Armada-press, 697 p.

[58] Sinelnikov, V. (2011). Great power of life. Moscow: Tsentrpoligraf, $558 \mathrm{p}$.

[59] Kurienè, A. (2016). How to raise a man. Vilnius: Alma Litera, $221 \mathrm{p}$. 